\title{
The effect of condensed tannins on the site of digestion of amino acids and other nutrients in sheep fed on Lotus corniculatus $L$.
}

\author{
By G. C. WAGHORN, M. J. ULYATT, A. JOHN AND M. T. FISHER \\ Applied Biochemistry Division, DSIR, Palmerston North, New Zealand
}

(Received 2 April 1986 - Accepted 19 August 1986)

\begin{abstract}
1. Sheep were used to evaluate the nutritional consequences of a low condensed-tannin concentration $(22 \mathrm{~g} / \mathrm{kg}$ dry matter (DM)) in lotus (Lotus corniculatus L.) (control group) compared with lotus given to sheep receiving intraruminal polyethylene glycol (PEG) infusion (PEG group). PEG selectively binds to tannins and prevents tannins from binding proteins.

2. DM intakes (1430 (SE 28) g/d) and digestibility of energy (663 (SE 4.5) kJ/MJ intake) were similar for both groups but the apparent digestion of nitrogen was lower in the control sheep $(0.70)$ than in the PEG sheep $(0.78$; $P<0.001$ ).

3. The proportion of $\mathrm{N}$ apparently digested before the abomasum (i.e. in the rumen) was lower $(P<0.05)$ in control sheep $(0.12)$ than in PEG sheep $(0.21 ; P<0.05)$. Rumen ammonia concentrations were lower $(P<0.001)$ in control sheep than in PEG sheep. The proportion of neutral-detergent fibre (NDF) digested in the rumen was similar for both groups $(0.48$ (SE 0.012$)$ ) but less energy was digested in the rumen of the control $(0.42)$ than of the PEG sheep $(0.47 ; P<0.05)$.

4. The flux of essential amino acids (EAA) through the abomasum of control sheep was $50 \%$ greater than that in PEG sheep; flux of non-essential amino acids (NEAA) was $14 \%$ higher in control than in PEG sheep. Apparent digestibility of EAA in the small intestine was similar for both treatments $(0.67)$, but NEAA were less well digested in the control (0.55) than in the PEG sheep (0.69).

5. The presence of tannins in the control group increased net apparent absorption of threonine (57\%), valine $(89 \%)$, isoleucine $(94 \%)$, leucine $(30 \%)$, tyrosine $(41 \%)$, phenylalanine $(93 \%)$, histidine $(90 \%)$ and lysine $(59 \%)$, and reduced NEAA absorption by $10 \%$, compared with PEG sheep.
\end{abstract}

Tannins are widespread in the plant kingdom and appear to be beneficial to ruminants in some instances. Condensed tannins bind to proteins to form stable complexes in the $\mathrm{pH}$ range $3.5-7.0$ but dissociate at $\mathrm{pH}<3.5$ and $>8.5$ (Jones \& Mangan, 1977). Plant proteins should therefore be bound and protected from microbial degradation in the rumen (pH 5.5-7.0) and released in the abomasum, enabling hydrolysis and absorption of amino acids (AA) to occur in the small intestine.

Conservation of dietary protein in the rumen of sheep fed on tannin-containing legumes has been demonstrated with both sainfoin (Onobrychis viciifolia Scop.) (Thomson et al. 1971; Ulyatt et al. 1977; Egan \& Ulyatt, 1980) and lotus (Lotus corniculatus) (John \& Lancashire, 1981; Barry \& Manley, 1984). Sainfoin diets have a lower nitrogen digestibility and a higher $\mathrm{N}$ retention than grasses and clovers fed at similar levels of intake (Ulyatt et al. 1977; Egan \& Ulyatt, 1980). The higher $N$ retention of sainfoin could not be explained in terms of urea-N recycling (Egan \& Ulyatt, 1980). Sheep fed on a lotus cultivar containing $14.5 \mathrm{~g}$ condensed tannin $/ \mathrm{kg}$ dry matter (DM) retained more $\mathrm{N}$ than those fed on a cultivar containing $2.5 \mathrm{~g}$ condensed tannin/ $\mathrm{kg} \mathrm{DM}$ (John \& Lancashire, 1981). Lotus species containing high concentrations of condensed tannins $(60-110 \mathrm{~g} / \mathrm{kg} \mathrm{DM})$ reduce voluntary intake and result in a low $\mathrm{N}$ digestibility $(0 \cdot 48-0 \cdot 71)$ when fed to sheep (Barry \& Duncan, 1984; Barry \& Manley, 1984).

The objective of the present experiment was to feed sheep high intakes of a lotus cultivar containing low levels of condensed tannins and to remove the effects of the tannins from half the animals by an intraruminal infusion of polyethylene glycol (PEG) (Jones \& Mangan, 1977). High levels of intake were intended to maximize the potential for $\mathrm{N}$ loss from the rumen (Ulyatt \& Egan, 1979) and therefore maximize the potential for tannins 
to bind, and later release, plant proteins. The effects of tannins were evaluated on the basis of nutrient digestion before the abomasum, in the small intestine and in the whole digestive tract. Although carbohydrate and mineral components have been measured, most emphasis has been placed on the digestion of nitrogenous constituents and the availability of individual AA for absorption.

\section{EXPERIMENTAL \\ Feed}

The lotus (cv. Maitland) was harvested from a vigorously growing stand $300-400 \mathrm{~mm}$ high in a pre-bloom vegetative state. The lotus was harvested daily at 08.00 hours and was cut to $30-50 \mathrm{~mm}$ lengths with a chaff cutter immediately after harvest. One-third of the daily requirement was placed on belt feeders (which delivered feed in hourly increments) by 09.00 hours, and the remaining two-thirds stored at $4^{\circ}$ until 16.00 hours and then placed on belt feeders.

Lotus was given for a total of $24 \mathrm{~d}$, and was offered ad lib. for the first $7 \mathrm{~d}$ and thereafter at $90 \%$ of ad lib. intake. A rapid DM determination by microwave oven enabled a consistent daily allocation of DM. Feed DM was confirmed by drying at $100^{\circ}$ for $24 \mathrm{~h}$. Fresh feed was subsampled daily and pooled samples stored at $-20^{\circ}$ for analysis.

\section{Animals}

Eight 18-month-old Romney Marsh wethers, mean weight 44 (SE 1.0) kg, had been fitted with rumen and abomasal ' $T$ ' piece cannulas 6 months previously, and were accustomed to handling. The sheep had been used for a previous experiment (Waghorn et al. 1987) and had been allowed 5-8 weeks grazing ryegrass (Lolium multiflorum Lam.)-clover (Trifolium repens $\mathrm{L}$.) pasture before returning to metabolism crates for the present experiment.

\section{Measurement sequence}

The sheep were randomly divided into two groups (four sheep per group). One group received a continuous infusion of $50 \mathrm{~g} \mathrm{PEG} / \mathrm{d}$ (molecular weight 3500 ; in $380 \mathrm{ml}$ water) into the rumen from day 14 until slaughter (PEG group) and the others received $430 \mathrm{ml}$ water/d (control group). A $20 \mathrm{ml}$ sample of strained rumen fluid was collected from each sheep immediately before and $3 \mathrm{~d}$ after infusions commenced, to determine ammonia levels. Rumen $\mathrm{NH}_{3}$ concentration indicates the effectiveness of PEG in binding tannins, enabling microbial degradation of unbound plant proteins (Jones \& Mangan, 1977; John \& Lancashire, 1981).

Sheep were fitted with harnesses and faecal collection bags on day 17 for digestibility measurements. Faeces were collected each day and frozen until analysed. Liquid- and solid-phase markers were added to the intrarumen infusate from day 18 until slaughter: CrEDTA was infused at $280 \mathrm{mg}$ chromium/d as the liquid-phase marker (Binnerts et al. 1968 ) and ${ }^{103} \mathrm{Ru}$ phenanthroline complex at $9 \mu \mathrm{Ci} / \mathrm{d}$ as the solid-phase marker (Tan et al. 1971). Abomasal digesta were sampled $(50-100 \mathrm{ml})$ at $6-8 \mathrm{~h}$ intervals from days 21 to 24 to represent a two-hourly sampling over $24 \mathrm{~h}$ (Ulyatt \& Egan, 1979). Samples were refrigerated $\left(4^{\circ}\right)$ immediately, and when the final samples were obtained the twelve samples from each sheep were combined on an equal volume basis and frozen until analysed.

Feeding and marker infusion continued until $5 \mathrm{~min}$ before slaughter on day 24 of the experiment. Sheep were killed by intravenous administration of sodium pentabarbital, a midline incision made in the abdomen and the terminal ileum located and sectioned. Ileal digesta were gently 'milked' from about $4 \mathrm{~m}$ of the terminal ileum, yielding 250-350 g wet material which was stored at $-20^{\circ}$ for analyses. Ileal digesta were collected within 2 min of death. 


\section{Analyses}

Flow of digesta through the abomasum and ileum was determined by the double-marker method of Faichney (1975). This requires both $\mathrm{Cr}$ concentrations and ${ }^{103} \mathrm{Ru}$ activity to be determined in whole digesta and supernatant $(29000 \mathrm{~g})$ fractions. Whole digesta were prepared for $\mathrm{Cr}$ analyses by 'wet ashing' $0.3 \mathrm{~g} \mathrm{DM}$ in $10 \mathrm{ml}$ concentrated nitric acid for $3 \mathrm{~d}$ and resuspension in $2 \mathrm{M}$-hydrochloric acid (Grace, 1983). The supernatant fraction was diluted with an equal volume of $4 \mathrm{M}-\mathrm{HCl}$. Cr concentrations were determined by inductively coupled argon plasma spectrometry (ICAPS) (Lee, 1981), ${ }^{103} \mathrm{Ru}$ activity in whole digesta and supernatant fraction was determined using a gamma counter (Packard).

On the basis of these determinations, abomasal digesta flows were calculated and digesta from each sheep reconstituted (Faichney, 1975) for DM determination and chemical analysis. Very low values for $\mathrm{Cr}$ in the ileal supernatant fraction suggested matrix interference in the analyses, so that ileal flow rates were calculated from ${ }^{103} \mathrm{Ru}$ activity/unit ileal DM, and were not reconstituted for analysis.

Feed, digesta and faecal samples were freeze dried and ground for determination of ash, neutral-detergent fibre (NDF), lignin, energy, $\mathrm{N}$ and total (hydrolysed) AA concentrations. Structural carbohydrates were determined by sequential neutral-detergent, then acid extractions (Robertson \& Van Soest, 1980); energy by bomb calorimetry; and $\mathrm{N}$ by auto-analysis of $\mathrm{NH}_{3}$ following Kjeldahl digestion (Williams \& Twine, 1967). AA concentrations were determined in feed (duplicate) and in abomasal and ileal digesta after hydrolysis (Association of Official Analytical Chemists, 1982) and separation on an LKB analyser (Fisher, 1983). Sulphur-containing AA could not be determined accurately by this technique, and are not reported. Methods for determining monosaccharides, starch, pectin and lipids in feed have been summarized by Ulyatt \& Macrae (1974).

Rumen $\mathrm{NH}_{3}$ was determined by autoanalysis (Technicon Industrial Systems, 1973) and condensed tannins by acidified vanillin (Broadhurst \& Jones, 1978). Mineral elements in plant, digesta and faecal samples were determined by the same 'wet ashing' procedures as described for $\mathrm{Cr}$, and analyses by ICAPS.

All concentrations of nutrients in digesta and faeces, and fluxes of digesta and faeces, are expressed on a 'PEG free' basis. Fluxes of nutrients are determined from DM flux and concentration of nutrients in DM. Apparent absorption is the disappearance between two sites. All presentations of AA results as ratios of EAA: NEAA exclude S-containing AA, and include tyrosine as an EAA because the only source is phenylalanine. This also applies to the discussion of results from other experiments.

\section{Statistical analyses}

Means are presented with the standard errors of the means, or with pooled standard errors, as appropriate. Comparison between control and PEG treatments were made by analysis of variance.

\section{RESULTS}

Lotus DM was 165 (SE 6.3) $\mathrm{g} / \mathrm{kg}$ over the duration of the experiment. Lotus DM composition was $(\mathrm{g} / \mathrm{kg}): 88$ ash, 84 monosaccharides, 44 starch, 45 pectin, $485 \mathrm{NDF}, 103$ lignin, $27 \mathrm{~N}, 47$ diethyl-ether-extractable lipid, and contained $18.72 \mathrm{~kJ}$ gross energy (GE) per g. The concentration of condensed tannins was $21.7 \mathrm{~g} / \mathrm{kg}$ lotus DM. Feed intakes by the control and PEG groups during the digestion period were 1400 and $1461 \mathrm{~g} \mathrm{DM} / \mathrm{d}$ respectively (not significant, Table 1 ).

Rumen $\mathrm{NH}_{3}$ concentrations $(\mu \mathrm{g} / \mathrm{ml}$ rumen fluid) before PEG infusion were similar for the control (348 (SE 42.6)) and PEG (320 (SE 5.8)) treatments but, after $3 \mathrm{~d}$ of PEG infusion, 
Table 1. Intake, digestibility and flow of polyethylene glycol (PEG)-free digesta through the abomasum and terminal ileum of sheep fed on lotus (Lotus corniculatus L. (cv. Maitland)) with and without administration of $P E G$

(Mean values for four animals per treatment with their pooled standard errors)

\begin{tabular}{|c|c|c|c|}
\hline & $\begin{array}{l}\text { Control } \\
\text { sheep } \\
\text { (mean) }\end{array}$ & $\begin{array}{c}\text { PEG } \\
\text { sheep } \\
\text { (mean) }\end{array}$ & $\begin{array}{l}\text { Pooled } \\
\text { SEM }\end{array}$ \\
\hline DM intake $(g / d)$ & 1400 & 1461 & $27 \cdot 3$ \\
\hline \multicolumn{4}{|c|}{ Digestibility (proportion of intake): } \\
\hline DM & 0.69 & $0 \cdot 71$ & 0.005 \\
\hline Energy & 0.66 & 0.67 & 0.005 \\
\hline $\mathrm{NDF}$ & 0.60 & 0.62 & 0.007 \\
\hline \multicolumn{4}{|c|}{ Flow through the abomasum $(\mathrm{g} / \mathrm{d})$ : } \\
\hline DM & 874 & 825 & $20 \cdot 3$ \\
\hline Abomasal digesta & 23743 & 25270 & 1380 \\
\hline \multicolumn{4}{|c|}{ Flow through the ileum $(\mathrm{g} / \mathrm{d})$ : } \\
\hline DM & 544 & 514 & $14 \cdot 9$ \\
\hline Ileal digesta & 6860 & 6397 & 258 \\
\hline Faecal DM output (g/d) & 442 & 427 & $13 \cdot 7$ \\
\hline
\end{tabular}

DM, dry matter; NDF, neutral-detergent fibre.

Table 2. Concentration $(\mathrm{g} / \mathrm{kg}$ dry matter $(D M))$ of metabolites and energy in polyethylene glycol (PEG)-free abomasal and ileal contents and faeces of sheep fed on lotus (Lotus corniculatus L. (cv. Maitland)) with and without infusion of $P E G$

(Mean values for four animals per treatment with their pooled standard errors)

\begin{tabular}{|c|c|c|c|c|}
\hline & $\begin{array}{l}\text { Control } \\
\text { sheep } \\
\text { (mean) }\end{array}$ & $\begin{array}{c}\text { PEG } \\
\text { sheep } \\
\text { (mean) }\end{array}$ & $\begin{array}{c}\text { Pooled } \\
\text { SEM }\end{array}$ & $\begin{array}{l}\text { Statistical } \\
\text { significance of } \\
\text { difference }\end{array}$ \\
\hline \multicolumn{5}{|l|}{ Abomasal digesta: } \\
\hline Ash & 182 & 201 & $3 \cdot 9$ & $P<0.10$ \\
\hline Nitrogen & 38 & 38 & 0.4 & NS \\
\hline $\mathrm{AA}$ & 192 & 162 & $6 \cdot 0$ & $P<0.05$ \\
\hline NDF & 405 & 441 & $7 \cdot 8$ & NS \\
\hline Lignin & 124 & 133 & $4 \cdot 1$ & NS \\
\hline Energy $(\mathrm{kJ} / \mathrm{g}$ DM) & $17 \cdot 4$ & $17 \cdot 8$ & $0 \cdot 20$ & NS \\
\hline \multicolumn{5}{|c|}{ Abomasal supernatant fraction: } \\
\hline Ash & 182 & 182 & $3 \cdot 0$ & NS \\
\hline Ammonia $(\mu \mathrm{g} / \mathrm{ml})$ & 205 & 211 & $5 \cdot 2$ & NS \\
\hline \multicolumn{5}{|l|}{ Ileal digesta: } \\
\hline Ash & 158 & 153 & $5 \cdot 0$ & NS \\
\hline $\mathbf{N}$ & 25 & 18 & 0.5 & $P<0.001$ \\
\hline AA & 106 & 84 & $2 \cdot 5$ & $P<0.01$ \\
\hline NDF & 553 & 615 & $26 \cdot 0$ & $P<0.05$ \\
\hline Lignin & 172 & 192 & 4.7 & $P<0.05$ \\
\hline Energy (kJ/g DM) & $18 \cdot 1$ & $18 \cdot 4$ & 0.25 & NS \\
\hline \multicolumn{5}{|l|}{ Faeces: } \\
\hline Ash & 107 & 104 & $2 \cdot 0$ & NS \\
\hline $\mathrm{N}$ & 26 & 20 & 0.5 & $P<0.01$ \\
\hline NDF & 620 & 640 & $5 \cdot 3$ & $P<0 \cdot 10$ \\
\hline Lignin & 236 & 236 & $3 \cdot 3$ & NS \\
\hline Energy $(\mathrm{kJ} / \mathrm{g} \mathrm{DM})$ & $20 \cdot 3$ & $21 \cdot 3$ & 0.11 & $P<0.01$ \\
\hline
\end{tabular}

AA, amino acids; NDF, neutral-detergent fibre; NS, not significant. 
Table 3. Nitrogen and non-ammonia-N $(N A N)$ flow through the alimentary tract, and sites of digestion in sheep fed on lotus (Lotus corniculatus $L$. (cv. Maitland)) with and without infusion of polyethylene glycol (PEG)

(Mean values for four animals per treatment with their pooled standard errors)

\begin{tabular}{|c|c|c|c|c|}
\hline & $\begin{array}{l}\text { Control } \\
\text { sheep } \\
\text { (mean) }\end{array}$ & $\begin{array}{c}\text { PEG } \\
\text { sheep } \\
\text { (mean) }\end{array}$ & $\begin{array}{l}\text { Pooled } \\
\text { SEM }\end{array}$ & $\begin{array}{l}\text { Statistical } \\
\text { significance of } \\
\text { difference }\end{array}$ \\
\hline Intake of $N^{*}(g / d)$ & 37.8 & $37 \cdot 8$ & - & - \\
\hline \multicolumn{5}{|l|}{ Abomasal N: } \\
\hline Total $N$ flow $(\mathrm{g} / \mathrm{d})$ & $33 \cdot 4$ & $29 \cdot 8$ & 0.63 & $P<0.05$ \\
\hline $\mathrm{NH}_{3}$ flow $(\mathrm{g} / \mathrm{d})$ & 3.9 & $4 \cdot 0$ & $0 \cdot 12$ & NS \\
\hline NAN flow $(\mathrm{g} / \mathrm{d})$ & $29 \cdot 5$ & 25.8 & 0.58 & $P<0.05$ \\
\hline NAN (mg/g N intake) & 781 & 683 & $15 \cdot 2$ & $P<0.05$ \\
\hline Ileal $N$ flow $(\mathrm{g} / \mathrm{d})$ & $13 \cdot 5$ & $8 \cdot 8$ & 0.51 & $P<0.01$ \\
\hline Faecal $N(g / d)$ & $11 \cdot 3$ & $8 \cdot 3$ & $0 \cdot 118$ & $P<0.001$ \\
\hline \multicolumn{5}{|c|}{ Apparent digestion of $N(g / d)$ : } \\
\hline Total & $26 \cdot 5$ & $29 \cdot 5$ & 0.18 & $P<0.001$ \\
\hline Rumen (pre-abomasal) & $4 \cdot 4$ & 7.9 & 0.63 & $P<0.05$ \\
\hline Small intestine & 19.9 & $21 \cdot 0$ & 0.79 & NS \\
\hline Large intestine & $2 \cdot 2$ & $0 \cdot 50$ & 0.54 & NS \\
\hline \multicolumn{5}{|l|}{$\begin{array}{l}\text { Apparent digestion of } \mathrm{N} \\
\text { (proportion of intake): }\end{array}$} \\
\hline Total & $0 \cdot 70$ & 0.78 & 0.005 & $P<0.001$ \\
\hline Rumen (pre-abomasal) & $0 \cdot 12$ & $0 \cdot 21$ & 0.017 & $P<0.05$ \\
\hline Small intestine & 0.52 & 0.56 & 0.021 & NS \\
\hline Large intestine & 0.06 & 0.01 & 0.014 & NS \\
\hline
\end{tabular}

* Values for PEG sheep have been adjusted to a dry matter intake of $1400 \mathrm{~g} / \mathrm{d}$. NS, not significant.

rumen $\mathrm{NH}_{3}$ increased $(P<0.001)$ to 504 (SE 28.7), while the control group remained unchanged at 367 (SE 12.1) $\mu \mathrm{g} / \mathrm{ml}$ rumen fluid.

Infusion of PEG did not affect the apparent digestibility of DM, energy or NDF or the flux of DM or whole digesta through the abomasum or ileum (Table 1).

\section{$N$ digestion}

The principal effect of PEG infusion was on the digestion of $\mathrm{N}$ (Tables 2 and 3). Although the concentrations of $\mathrm{N}$ and $\mathrm{NH}_{3}$ in abomasal digesta were the same for the two treatments (Table 2), the non- $\mathrm{NH}_{3}-\mathrm{N}$ (NAN) flux through the abomasum (as a percentage of $\mathrm{N}$ intake) was greater in the control sheep $(P<0.05)$. The control sheep apparently digested less dietary $\mathrm{N}$ in the rumen $(11.7 \%)$ compared with the PEG sheep $(21.0 \% ; P<0.05)$ and had a higher $(P<0.05)$ concentration of AA in abomasal digesta than the PEG group (Table 2).

Ileal digesta of control sheep had higher $\mathrm{N}(P<0.001)$ and AA $(P<0.01)$ concentrations than those of the PEG sheep (Table 2), so that the apparent digestion of $\mathbf{N}$ in the small intestine was similar for both treatments (Table 3).

Faecal N concentration was higher in the control sheep than in the PEG sheep $(P<0 \cdot 01)$ and total apparent digestion of $\mathrm{N}$ (as a percentage of intake) was lower $(P<0.001)$ in the control sheep $(70 \cdot 1 \%)$ than in the PEG sheep $(78.1 \%$; Table 3$)$.

\section{AA digestion}

Lotus contained $153 \mathrm{mg} \mathrm{AA} / \mathrm{g}$ DM. Feed intakes by the control and PEG sheep were 214 (SE 6.5) and 224 (SE 5.3) g AA/d. Abomasal AA fluxes were 167 (SE 5.8) and 133 (SE 


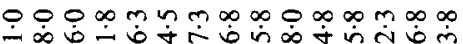

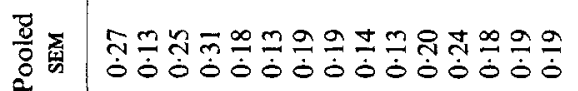

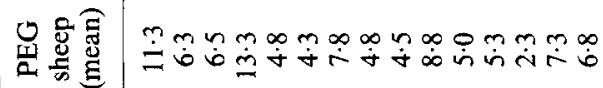

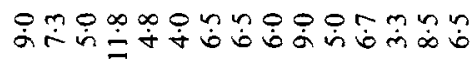

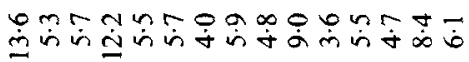


Table 5. Amino acid (AA) intake, flux through abomasum and apparent loss in the rumen of sheep fed on lotus (Lotus corniculatus L. (cv. Maitland)) with and without infusion of polyethylene glycol (PEG)

(Mean values for four animals per treatment with their pooled standard errors)

\begin{tabular}{|c|c|c|c|c|c|c|c|c|}
\hline \multirow[b]{2}{*}{ Amino acid } & \multirow[b]{2}{*}{ Essentiality } & \multirow[b]{2}{*}{$\begin{array}{l}\text { Intake* } \\
(\mathrm{g} / \mathrm{d})\end{array}$} & \multicolumn{2}{|c|}{$\begin{array}{l}\text { Flux of AA through } \\
\text { abomasum }(\mathrm{g} / \mathrm{d})\end{array}$} & \multicolumn{2}{|c|}{$\begin{array}{l}\text { Loss of } A A \text { in } \\
\text { rumen }(g / d)\end{array}$} & \multirow[b]{2}{*}{$\begin{array}{l}\text { Pooled } \\
\text { SEM }\end{array}$} & \multirow[b]{2}{*}{$\begin{array}{l}\text { Statistical } \\
\text { significance of } \\
\text { difference } \dagger\end{array}$} \\
\hline & & & $\begin{array}{c}\text { Control } \\
\text { sheep } \\
\text { (mean) }\end{array}$ & $\begin{array}{c}\text { PEG } \\
\text { sheep } \\
\text { (mean) }\end{array}$ & $\begin{array}{c}\text { Control } \\
\text { sheep } \\
\text { (mean) }\end{array}$ & $\begin{array}{c}\text { PEG } \\
\text { sheep } \\
\text { (mean) }\end{array}$ & & \\
\hline Asparagine & & $28 \cdot 6$ & 14.9 & $14 \cdot 0$ & $13 \cdot 8$ & $14 \cdot 6$ & 0.51 & NS \\
\hline Threonine & $E$ & $11 \cdot 1$ & $11 \cdot 8$ & $7 \cdot 8$ & -0.7 & $3 \cdot 3$ & $0 \cdot 33$ & $P<0.001$ \\
\hline Serine & & 11.9 & $8 \cdot 2$ & $8 \cdot 1$ & 3.7 & 3.8 & $0 \cdot 36$ & NS \\
\hline Glutamate & & $25 \cdot 6$ & 19.7 & $16 \cdot 5$ & 5.9 & $9 \cdot 1$ & 0.58 & $P<0.05$ \\
\hline Proline & & $11 \cdot 6$ & $8 \cdot 3$ & $6 \cdot 4$ & $3 \cdot 3$ & $5 \cdot 2$ & 0.32 & $P<0.05$ \\
\hline Glycine & & $11 \cdot 8$ & 6.7 & $5 \cdot 3$ & $5 \cdot 1$ & 6.5 & 0.22 & $P<0.05$ \\
\hline Alanine & & $8 \cdot 4$ & $10 \cdot 8$ & $9 \cdot 7$ & $-2 \cdot 4$ & $-1 \cdot 3$ & 0.34 & NS \\
\hline Valine & $\mathrm{E}$ & $12 \cdot 3$ & $10 \cdot 8$ & $6 \cdot 2$ & $1 \cdot 5$ & $6 \cdot 1$ & $0 \cdot 36$ & $P<0.001$ \\
\hline Isoleucine & $\mathrm{E}$ & $10 \cdot 1$ & $9 \cdot 6$ & $5 \cdot 6$ & 0.5 & $4 \cdot 5$ & $0 \cdot 33$ & $P<0.001$ \\
\hline Leucine & $\mathbf{E}$ & $18 \cdot 9$ & $14 \cdot 7$ & $10 \cdot 8$ & $4 \cdot 2$ & $8 \cdot 1$ & 0.47 & $P<0.01$ \\
\hline Tyrosine & $\bar{E}^{t}$ & $7 \cdot 6$ & $8 \cdot 0$ & $6 \cdot 3$ & -0.4 & 1.4 & 0.43 & NS \\
\hline Phenylalanine & $\mathbf{E}$ & $11 \cdot 6$ & $10 \cdot 7$ & $6 \cdot 6$ & 0.9 & $5 \cdot 0$ & 0.62 & $P<0.05$ \\
\hline Histidine & $\mathrm{E}$ & $9 \cdot 8$ & $5 \cdot 3$ & $3 \cdot 0$ & $4 \cdot 5$ & 6.8 & 0.28 & $P<0.01$ \\
\hline Lysine & $\mathbf{E}$ & $17 \cdot 5$ & $13 \cdot 8$ & $9 \cdot 2$ & $3 \cdot 7$ & $8 \cdot 3$ & 0.60 & $P<0.01$ \\
\hline Arginine & E & $12 \cdot 9$ & $11 \cdot 0$ & $8 \cdot 4$ & $2 \cdot 1$ & $4 \cdot 5$ & 0.50 & $P<0.05$ \\
\hline $\mathrm{EAA}$ & & 111.8 & 95.6 & 63.9 & $16 \cdot 2$ & 47.9 & $3 \cdot 20$ & $P<0.01$ \\
\hline NEAA & & 97.9 & $68 \cdot 5$ & $60 \cdot 0$ & $29 \cdot 4$ & 37.9 & $2 \cdot 10$ & $P<0.10$ \\
\hline
\end{tabular}

NS, not significant; EAA, essential, NEAA, non-essential AA.

${ }^{t}$ Essential in that only source is phenylalanine.

* Values for PEG sheep have been adjusted to an intake of $1400 \mathrm{~g}$ dry matter/d.

$\dagger$ Apparent loss in the rumen is the intake minus the abomasal flux, so that the test of significance applies to both sets of values.

$8 \cdot 2) \mathrm{g} / \mathrm{d}$, suggesting a pre-abomasal apparent loss of 22 and $40 \%$ of dietary AA in the control and PEG sheep respectively.

Abomasal digesta from control sheep had significantly higher concentrations of valine and isoleucine $(P<0.01)$ and threonine, phenylalanine, lysine and histidine $(P<0.05)$, but lower concentrations of aspartate $(P<0.01)$ and of serine and alanine $(P<0.05)$ than those of PEG sheep (Table 4). The flux of AA through the abomasum (corrected to equal DM intakes) shows that the control sheep had a significantly greater flux of threonine, valine, isoleucine $(P<0.001)$, leucine, histidine, lysine $(P<0.01)$, glutamate proline, glycine, phenylalanine and arginine $(P<0.05)$ than the PEG sheep (Table 5).

The AA flux at the ileum was 58 (SE 3.5) and 43 (SE 2.0) g/d for the control and PEG sheep respectively. The apparent AA absorptions in the small intestine were 109 (SE 5.5) (control) and 90 (SE 7.3) (PEG) g/d, or 51 and $40 \%$ of the respective AA intakes.

Ileal digesta from control sheep contained higher concentrations of aspartate $(P<0.01)$, glutamate and proline $(P<0.05)$, and lower concentrations of phenylalanine $(P<0.01)$ and tyrosine $(P<0.05)$ than PEG sheep (Table 4$)$. The control sheep had a higher flux at the terminal ileum of aspartate, serine, glutamate, proline, glycine, alanine, valine, isoleucine $(P<0.01)$, threonine and leucine $(P<0.05)$ than the PEG sheep.

The effects of PEG treatment on apparent absorption of individual AA in the small intestine, and their apparent digestibility, are summarized in Table 6. Control sheep 





Table 7. Intake and apparent absorption of macroelements before the abomasum (pre-abo), in the small intestine $(S I)$ and in the large intestine $(L I)$ of sheep fed on lotus (Lotus corniculatus L. (cv. Maitland))

(Values for diets with and without infusion of polyethylene glycol are combined mean values with their standard errors for eight animals)

\begin{tabular}{|c|c|c|c|c|c|c|c|c|}
\hline & \multirow{3}{*}{$\begin{array}{c}\text { Intake } \\
(\mathrm{g} / \mathrm{d})\end{array}$} & \multirow{3}{*}{$\begin{array}{c}\text { Absorption } \\
\text { (proportion } \\
\text { of intake) }\end{array}$} & \multicolumn{6}{|c|}{ Absorption $(\mathrm{g} / \mathrm{d})$} \\
\hline & & & \multicolumn{2}{|c|}{ Pre-abo } & \multicolumn{2}{|c|}{ SI } & \multicolumn{2}{|c|}{ LI } \\
\hline & & & Mean & SE & Mean & SE & Mean & $\mathrm{SE}$ \\
\hline Calcium & $12 \cdot 47$ & 0.05 & -0.74 & 0.40 & 1.08 & 0.76 & 0.25 & 0.75 \\
\hline Potassium & $56 \cdot 81$ & 0.89 & $3 \cdot 52$ & $2 \cdot 24$ & $41 \cdot 09$ & $2 \cdot 73$ & $5 \cdot 88$ & $1 \cdot 64$ \\
\hline Magnesium & $2 \cdot 71$ & $0 \cdot 29$ & 0.72 & 0.05 & 0.03 & $0 \cdot 12$ & 0.04 & $0 \cdot 13$ \\
\hline Sodium & $1 \cdot 66^{*}$ & $0.67^{*}$ & $-11 \cdot 32^{*}$ & $1 \cdot 38$ & $-4 \cdot 69$ & 1.66 & $17 \cdot 11$ & $1 \cdot 40$ \\
\hline Phosphorus & $4 \cdot 56$ & 0.23 & -6.63 & 0.42 & $7 \cdot 54$ & 0.55 & 0.15 & 0.32 \\
\hline Sulphur & 3.67 & 0.47 & 0.62 & $0 \cdot 13$ & 0.65 & 0.15 & 0.48 & $0 \cdot 19$ \\
\hline
\end{tabular}

* Actual intakes may have been increased from sodium chloride supplement (available in block form, free choice).

absorbed more valine $(P<0.001)$, threonine, isoleucine $(P<0.01)$, leucine, tyrosine, phenylalanine, histidine and lysine $(P<0.05)$ and less aspartate $(P<0.05)$ than PEG sheep. This indicates that the apparent absorption in the small intestine of AA essential to the sheep (EAA), including tyrosine, was $62 \%$ greater with $22 \mathrm{~g}$ condensed tannins $/ \mathrm{kg}$ dietary DM than when the tannins were inactivated by PEG. About $10 \%$ less non-EAA (NEAA) were apparently absorbed from the small intestine in the control sheep, compared with the PEG sheep.

The apparent digestibility of AA in the small intestine of control sheep was lower for aspartate $(P<0.001)$, serine, glutamate, alanine $(P<0.01)$ and proline $(P<0.05)$ but, with the exception of phenylalanine, EAA digestibility was unaffected by tannins (Table $6)$.

\section{Carbohydrate digestion}

Effects of PEG on non-nitrogenous constituents were minor. Although the digestion of energy was similar in both treatments (0.66 (SE 0.004)) the proportion of energy intake digested in the rumen was lower $(P<0.05)$ in control sheep $(0.42$ (SE 0.011)) than in PEG sheep (0.47 (SE 0.012)). This was not due to differences in NDF digestion in the rumen. Control sheep digested 0.48 (SE 0.017) and PEG sheep 0.49 (SE 0.016) of NDF intake in the rumen.

There were no treatment effects on digestion of energy in the small $(0 \cdot 19$ (SE 0.015)) and large $(0.03$ (SE 0.012)) intestines, or on digestion of NDF in the small $(0.07$ (SE 0.026$)$ ) and large (0.05 (SE 0.014)) intestines. The higher concentrations of NDF and lignin in ileal digesta of PEG sheep (Table 2) are probably a reflection of protein absorption from digesta of this group.

\section{Mineral digestion}

Intakes and apparent absorption of macroelements are summarized in Table 7. The only effect of PEG was to increase apparent absorption of sulphur, potassium and magnesium.

Apparent absorption of $\mathrm{S}$ was 1.67 (SE 0.051) g/d in control sheep compared with 1.88 (SE 0.021) $\mathrm{g} / \mathrm{d}$ in the PEG group $(P<0.01)$. This effect was primarily due to a low apparent absorption pre-abomasum $(0.29$ (SE 0.092$) \mathrm{g} / \mathrm{d})$ in the control sheep compared with 0.94 $(\mathrm{SE} 0.081) \mathrm{g} / \mathrm{d}$ in the PEG sheep $(P<0.01)$. 
Apparent absorption of $\mathrm{K}$ was also lower $(P<0.05)$ in control sheep $(47.7$ (SE 1.22) $\mathrm{g} / \mathrm{d})$ compared with PEG sheep (53.4 (SE 1.16) g/d). Apparent absorption of Mg was slightly lower when tannins were present, 0.73 (SE 0.020) $\mathrm{g} / \mathrm{d}$ compared with the PEG sheep, 0.85 (SE 0.045$) \mathrm{g} / \mathrm{d}(P<0 \cdot 10)$. The effect of PEG on $\mathrm{K}$ and $\mathrm{Mg}$ absorption could not be attributed to specific sites of digestion.

\section{DISCUSSION}

Possible effects of excessive amounts of PEG on digestion were avoided by infusing only $50 \mathrm{~g} / \mathrm{d}(1 \cdot 7 \mathrm{~g} \mathrm{PEG} / \mathrm{g}$ tannins) which would displace (Jones \& Mangan, 1977) and completely bind all available tannins (Barry \& Forss, 1983). The similarity of intakes, digestibility of energy and NDF suggests minimal effects of PEG on non-nitrogenous components.

The lower apparent digestion of $\mathrm{N}$ in the control group, compared with those receiving PEG infusion, is consistent with other reports (e.g. Egan \& Ulyatt, 1980) of low N digestion in tannin-containing legumes. The increase in rumen $\mathrm{NH}_{3}$ concentration with $\mathrm{PEG}$ infusion provided indirect evidence that PEG was able to remove the protein protection derived through the presence of tannins. The effect of tannins in reducing rumen proteolysis was further evidenced by the higher abomasal NAN and AA fluxes, and lower digestion of energy, but not NDF, and of $S$ in the rumen of the control sheep. Although the apparent digestion of NAN in the small intestine was similar in both groups, the higher ileal AA and $\mathrm{N}$ concentrations in the control sheep suggested that the theoretical release of tannin-bound plant proteins for digestion in the small intestine was not complete.

The nutritional advantage conferred by tannins was primarily pre-abomasal and apparently a consequence of reduced microbial degradation of plant proteins in the rumen. In addition to increasing the AA flux to the abomasum, tannins appear to have affected a change in AA composition. The EAA: NEAA value in abomasal digesta was 1.40 for control sheep, compared with 1.08 for PEG sheep, so that at equal intakes the flux of abomasal digesta in control sheep contained $50 \%$ more EAA and $14 \%$ more NEAA than PEG sheep.

The EAA: NEAA value in lotus was 1.14 and in bacteria it is 1.08 (John, 1984) so that the value of 1.40 in abomasal digesta of control sheep could only arise from reduced microbial growth or selective protection of specific plant proteins, or both. Calculations of the effects of reduced microbial growth, or specific protection of Fraction 1 plant protein (ribulose1,5-biphosphate carboxylase-oxygenase (EC 4.1.1.39); Mangan, 1982) or other plant proteins $(65 \%$ of lotus protein; J. L. Mangan, personal communication) show that an alteration of the AA content of digesta protein leaving the rumen is theoretically possible. However, none of these options is able to effect an increase in the EAA:NEAA value recorded in the control sheep in this experiment.

John \& Lancashire (1981) reported a $15 \%$ decrease in microbial $\mathrm{N}$ and a $36 \%$ increase in plant $\mathrm{N}$ leaving the stomach of sheep fed on Lotus corniculatus cv. Maitland, which contained $14.5 \mathrm{~g}$ condensed tannins $/ \mathrm{kg}$ DM, compared with cv. Empire ( $2.5 \mathrm{~g}$ condensed tannins/kg DM); however, the AA fluxes were not determined. Studies of AA digestion in sheep have often showed small increases in the EAA: NEAA value between feed and duodenal digesta. Five dried diets (including dried sainfoin) had EAA:NEAA values of 0.97-1.05, and, when given to sheep, the EAA:NEAA values in duodenal digesta were 1.01-1.19 (Harrison et al. 1973). These authors also gave fresh red clover, where feed and digesta values were 1.00 and 1.10 respectively. In a study with sheep fed on fresh forages, MacRae \& Ulyatt (1974) showed respective feed and duodenal EAA: NEAA values to be 0.91 and 1.10 with white clover (Trifolium repens L.), 1.01 and 1.09 with perennial ryegrass 
(Lolium perenne L.) and 0.93 and 1.06 with short rotation ryegrass (L. multiflorum $\times$ perenne).

The possibility of analytical error being responsible for the very high EAA: NEAA value in abomasal digesta of control sheep (1.40) was considered. However, samples from both PEG and control sheep were treated in an identical manner from collection to AA determination. Also there was no reduction in the quality of AA separation or recovery of AA from hydrolysates of control digesta. Quality assurance material was routinely run with all batches of AA assayed, and gave AA concentrations well within expected analytical variation (Fisher et al. 1986).

The apparent digestibilities of EAA in the small intestine in the present experiment were slightly lower than comparable values from other green forages (MacRae \& Ulyatt, 1974). The presence of tannins was also associated with a significant depression in apparent digestibility of NEAA in control sheep. It is possible that digestion of all plant AA were depressed by tannins in the control sheep, and that 'essential' endogenous AA secretions were reabsorbed more effectively than 'non-essential' endogenous AA. The net effect of the lower apparent digestibility of NEAA in the control sheep was largely overcome by the higher AA flux to the abomasum, compared with the PEG group.

An increased absorption of EAA could account for the nutritional superiority and higher $\mathrm{N}$ retention reported in sheep fed on forages with low levels of condensed tannins (Ulyatt et al. 1977; Egan \& Ulyatt, 1980; John \& Lancashire, 1981). This could be further enhanced by an increased arginine absorption, and stimulation of growth hormone release with a consequent promotion of protein synthesis (Grodsky, 1979). Although apparent absorption of arginine could not be measured in this experiment, the abomasal flux was significantly higher in the presence of tannins.

It is evident that low levels of condensed tannins have dual advantages to ruminants fed on fresh forages. They promote higher rates of $\mathrm{N}$ retention than can be achieved from comparable tannin-free forages, and also prevent ruminants bloating (Jones \& Mangan, 1977). Further research is required to determine the mechanism by which the concentrations of EAA are selectively increased in abomasal digesta.

The authors wish to thank I. D. Shelton and B. R. Sinclair for technical assistance with animal handling and analyses; A. Allen, C. Gurnsey and G. Filby of the Analytical Laboratory for analyses of feed and digesta samples, and Dr W. Jones for advice concerning the determination of tannins.

\section{REFEREN CES}

Association of Official Analytical Chemists (1982) Journal of the Association of Official Analytical Chemists $\mathbf{6 5}$, 496.

Barry, T. N. \& Duncan, S. J. (1984). British Journal of Nutrition 51, 485-491.

Barry, T. N. \& Forss, D. A. (1983). Journal of the Science of Food and Agriculture 34, 1047-1056.

Barry, T. N. \& Manley, T. R. (1984). British Journal of Nutrition 51, 492-504.

Binnerts, W. T., van't Klooster, A. Th. \& Frens, A. M. (1968). Veterinary Record 82, 470-472.

Broadhurst, R. B. \& Jones, W. T. (1978). Journal of the Science of Food and Agriculture 29, 788-794.

Egan, A. R. \& Ulyatt, M. J. (1980). Journal of Agricultural Science, Cambridge 94, 47-56.

Faichney, G. J. (1975). In Digestion and Metabolism in the Ruminant, pp. 227-291 [I. W. McDonald and A. C. I. Warner, editors]. Armidale, Australia: University of New England Publishing Unit.

Fisher, M. T. (1983). In Symposium on Food Chemistry, pp. $28-40$ [E. L. Richards, editor]. Palmerston North, New Zealand: Massey University.

Fisher, M. T., Lee, J. \& Mara, K. M. (1986). Analyst (In the Press)

Grace, N. D. (1983). New Zealand Journal of Agricultural Research 26, 59-70.

Grodsky, G. M. (1979). In Review of Physiological Chemistry, pp. 556-568 [H. A. Harper, V. W. Rodwell and P. A. Nayes, editors]. Los Altos, California: Lange Medical Publications. 
Harrison, D. G., Beever, D. E., Thomson, D. J. \& Osbourn, D. F. (1973). Journal of Agricultural Science, Cambridge 81, 391-401.

John, A. (1984). Journal of Agricultural Science, Cambridge 102, 45-57.

John, A. \& Lancashire, J. A. (1981). Proceedings of the New Zealand Grassland Association 42, 152-159.

Jones, W. T. \& Mangan, J. L. (1977). Journal of the Science of Food and Agriculture 28, 126-136.

Lee, J. (1981). Technical Report no. 3. Palmerston North, New Zealand: Applied Biochemistry Division, DSIR.

MacRae, J. C. \& Ulyatt, M. J. (1974). Journal of Agricultural Science, Cambridge 82, 309-319.

Mangan, J. L. (1982). In Forage Protein in Ruminant Animal Production, Occasional Publication no. 6, pp. 25-40

[D. J. Thomson, D. E. Beever and R. G. Gunn, editors]. Milton Keynes: British Society of Animal Production.

Robertson, J. B. \& Van Soest, P. J. (1980). In Basic and Clinical Nutrition, vol. 3, pp. 123-158 [W. P. T. James and $\mathrm{O}$. Theander, editors]. New York: Marcel Dekker Inc.

Tan, T. N., Weston, R. H. \& Hogan, J. P. (1971). International Journal of Applied Radiation and Isotopes 22, 301-308.

Technicon Industrial Systems (1973). Autoanalyser II Method no. 270-73W. Tarrytown, NY 10591, USA: Technicon Ltd.

Thomson, D. J., Beever, D. E., Harrison, D. G., Hill, I. W. \& Osbourn, D. F. (1971). Proceedings of the Nutrition Society 30, 14A.

Ulyatt, M. J. \& Egan, A. R. (1979). Journal of Agricultural Science, Cambridge 92, 605-616.

Ulyatt, M. J., Lancashire, J. A. \& Jones, W. T. (1977). Proceedings of the New Zealand Grassland Association 38, $107-118$.

Ulyatt, M. J. \& Macrae, J. L. (1974). Journal of Agricultural Science, Cambridge 82, 295-307.

Waghorn, G. C., Flux, D. S. \& Ulyatt, M. J. (1987). Animal Production 44 (In the Press).

Williams, C. H. \& Twine, J. R. (1967). CSIRO Technical paper no. 24, pp. 119-126. Melbourne: CSIRO. 